\title{
Geological Study of Dasht-e-Top Sedimentary Basin, Wardak Province, Afghanistan
}

\author{
Hafizullah Rasouli, Shekeb Shamal, Mohammad Hasib Sarwari \\ Department of Geology, Geoscience Faculty, Kabul University, Kabul, Afghanistan \\ Email: hafizullah.rasouli133@gmail.com
}

How to cite this paper: Rasouli, $\mathrm{H}$. Shamal, S. and Sarwari, M.H. (2021) Geological Study of Dasht-e-Top Sedimentary Basin, Wardak Province, Afghanistan. International Journal of Geosciences, 12, 531-540. https://doi.org/10.4236/ijg.2021.126029

Received: March 7, 2021

Accepted: June 14, 2021

Published: June 17, 2021

Copyright $\odot 2021$ by author(s) and Scientific Research Publishing Inc. This work is licensed under the Creative Commons Attribution International License (CC BY 4.0).

http://creativecommons.org/licenses/by/4.0/

(c) (i) Open Access

\begin{abstract}
This study is conducted to investigate the occurrence of various geological features, and to study the geology and soil characteristics of the study area. To achieve the objective of this research collection, different samples from different locations in study area were collected, analyzed in laboratory, and the results are compared with each other. The main rock types found in the study area were metamorphic rock (Gneiss) and igneous rock (Granite), and the main soil types found were Loam, sandy and silty soils with different soil structures (e.g. crumbling, platy, single grain, granular and prismatic). Calcium carbonate, Iron oxides and different sizes of sediments were also seen in the soil profile, where the size of sediments were changing as it was course size sediments and gravels near the mountain range and as going far from the mountain it was changed to fine size sediments like sand, silt and clay. The river terraces present in the area cover different geological structures such as angular and erosional unconformities, thinning out of strata and potholes. The mountain range surrounded the study area contains different observable tectonic structures such as anticline, syncline, vines (dyke, sill and apophasis). Furthermore, different types of valleys also existed in this area.
\end{abstract}

\section{Keywords}

Petrography, Sediment Size, Soil Structure, River Terraces, Tectonic Structures, Geomorphology, Calcium Carbonate

\section{Introduction}

Dasht-e-top sedimentary basin is located $50 \mathrm{~km}$ west of Kabul in the Wardak province [1]. The surrounding mountains of Dasht-e-top are mainly composed of metamorphic and igneous rocks [2] [3], where, they are the essential part of the Paghman mountains range. Further information regarding gneisses of these 
mountains have need of both sedimentary and pedologic research with details [4]. The accumulated sediments are mostly clay, loam, sand and gravels, which are deposited in plane parts of the basin. The thickness of sediments depends on slope and distance from the mountains, and the basin has located at the two sides of Kandahar-Kabul highway and both sides are plane up to two $\mathrm{km}$, but close to the mountain there are hills and sloppy areas. All materials from different points of mountains are transported by floods and deposited at different parts in this basin [5] [6]. The age of sediments in this basin is Neogene-Pleistocene, and the sediment are in their normal position in the basin, where the lower layers are Neogene and the upper layers have Pleistocene age [7]. The Quality of sediments are directly referred to the type of mother rocks which eroded in the mountains. The size of materials also related to the distance of transportation from mountain ranges around the basin, where generally near to the mountains the sediments have very course to course sizes which include boulder, cobble, pebble and granules and with distance from mountains the size of material changes from fine to very fine and includes Sand, Silt and Clay. In mountainous area and its skirts, the grains are angular and sub angular but as getting far from mountains the grains become sub round and rounded [8] [9] [10]. In the soil profiles and river terraces different layers of materials can be seen, which is mainly due to oxidation, reductions and presence of $\mathrm{CaCO}_{3}$ and organic materials. Where, the red color shows oxidation and solution of iron oxide, white color is due to reduction and $\mathrm{CaCO}_{3}$ and the dark color is because of organic materials, that decomposed at the different periods of geology [11] [12] [13].

\section{Materials and Methods}

Generally, this research includes two parts.

\subsection{Field Work}

Field works are generally consisting the selection of points, collecting of the samples from the mountains (from different rock types present), field study of the sediments and all unconsolidated materials, study of the river terraces, Soil profiles, and existent structures of the area.

\subsection{Laboratory Works}

The laboratory works include the following procedures:

Air drying and oven drying of the collected sedimentary samples at $30^{\circ} \mathrm{C}$ for 24 hours, sieve analysis for determination of grain sizes of the soil samples, determination of $\mathrm{CaCO}_{3}$ by using calcimeter, and using of Polarized light microscopes for microscopic studies of the rock samples.

\section{Description of Site Studies}

This study was carried out in Dasht-e-top sedimentary basin (Figure 1) which is 


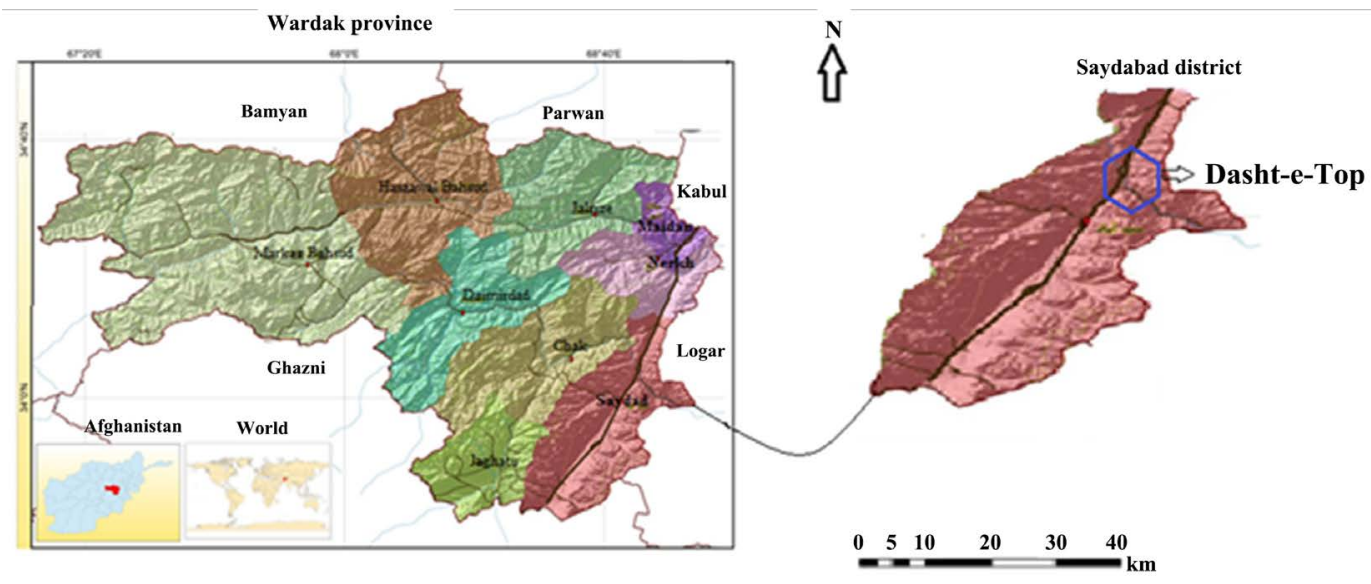

Figure 1. Location map of Dasht-e-top sedimentary basin, Wardak, Afghanistan.

a sub-basin of Wardak province. The study area is located between Logar, Paghman and Kabul Rivers, where Logar river flows at the west side of this basin [14] [15] [16]. Kabul River is located at the east, Paghman River and its mountain range are located at the south-east side of the study area. The total area of this basin is $6 \mathrm{~km}^{2}$ [17] [18] [19].

\section{Results and Discussion}

Generally the mountain ranges surrounding this sedimentary basin are consisting from metamorphic rock (Gneiss) and Igneous rock (Granite), and the accumulated sediments in this basin are Loam, Sands and Silts. The soil profile and river terraces in the area are showing different soil structures such as crumbling, platy, single grain, granular and prismatic. Furthermore, in the soil profile mostly $\mathrm{CaCO}_{3}$, iron oxides and different sizes of sediments can be seen, where the size of sediments are belonging to their travel distance from surrounded mountain ranges. Generally, sediments near to the mountain range are course size (e.g. gravels) and as we get away from mountains the grain size changes from fine to very fine Sands, Silt and Clay. River terraces are consisting of different structures of angular and erosional unconformities, layering thinning out and potholes. In mountainous areas, there are different tectonic structures such as anticline, syncline and different type of valleys.

\section{Geomorphology of Dasht-e-Top}

Generally, Dasht-e-top basin consists three types of relief, where the first type is sloppy areas, second is Skirt areas and hills and the third type is plain areas which are located at about $1 \mathrm{~km}$ at the two sides of Kabul-Kandahar road [20] [21]. The surrounding mountains of this basin is like ring (bowel) which is an inter mountains back basin [22].

\section{Geology}

The surrounding mountains of Dasht-e-top are formed from plutonic and me- 
tamorphic rocks (Granite, Gneiss). The mountains which surrounded this basin are belong to Paghman mountain range and it continue from NE to SW. Analysis of course sediments show that parent rocks are Gneiss and Granite and are present with different sizes in this basin (e.g. bolder, cobbles, pebbles and granules). In the surrounded mountain ranges, different types of valley structures such as longitudinal, diagonal, transverse, anticlinal and synclinal with magmatic inclusions like dikes and sills were also observed [23] (Figure 3). Furthermore, different types of sedimentary features like alluvial fans and alluvial aprons were also seen in the area (Figure 5).

\section{Country Rocks and Rock Boundaries}

The mountains of Dasht-e-Top have different lithology and geological age, there are close relation between rock boundaries, where the main rock types are gneisses and Granite which have Proterozoic age [23]. The contact zones of these rocks are different in different locations, in some areas Granite has contact with gneisses and in some parts, it is also observable with volcanic rocks which are younger than Granite and gneisses. These volcanic rocks are the Evidences to the occurrence of volcanic eruptions in the area [24] [25]. Different types of tectonic structures such as veins, dyke's sills and apophasis are observable in the abovementioned country rocks, and these rocks generally strikes from NE to SW and the surface dip is from $\mathrm{N}$ to SW (Figure 2, Figure 4).

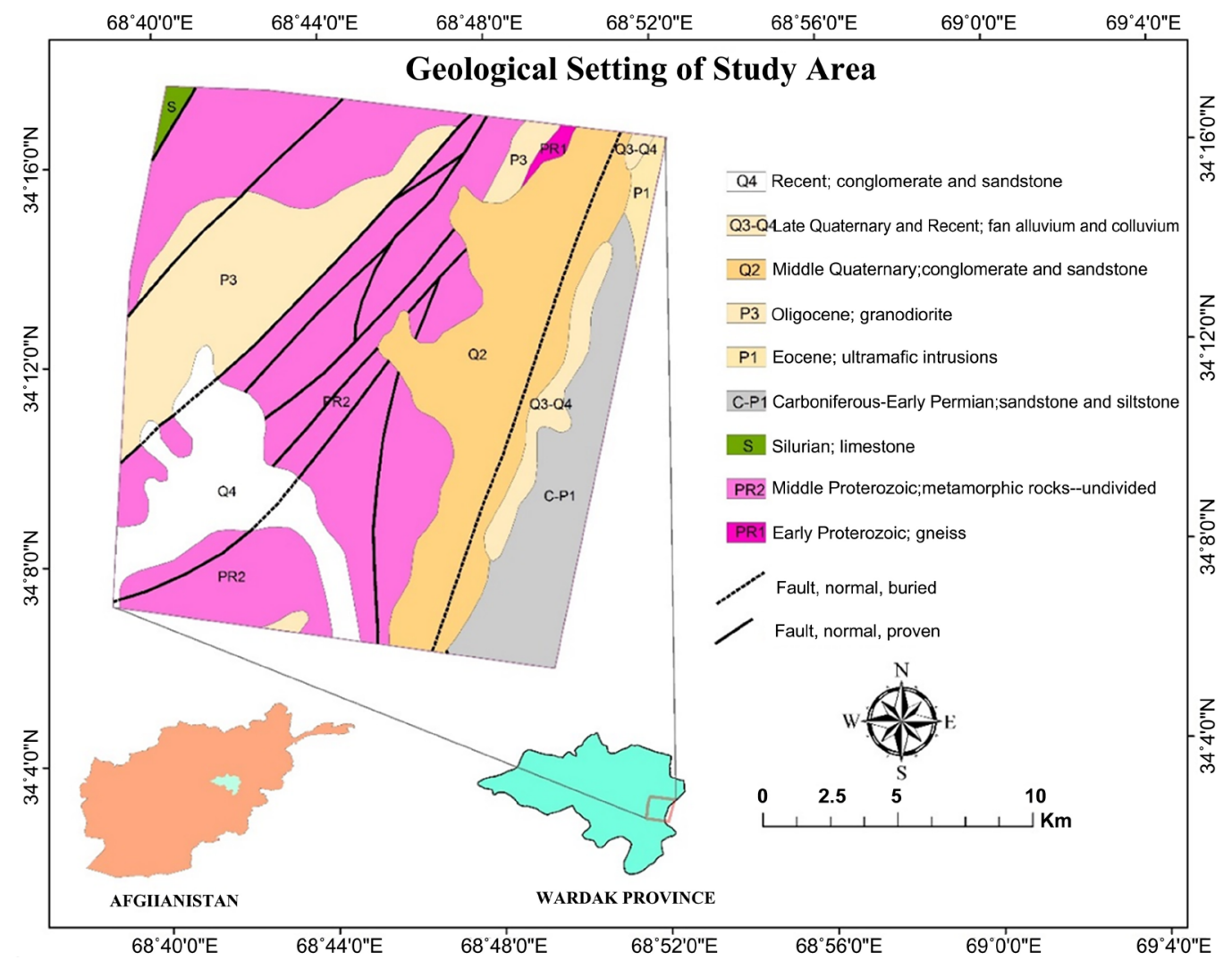

Figure 2. Geological map of Dasht-e-top sedimentary basin. 


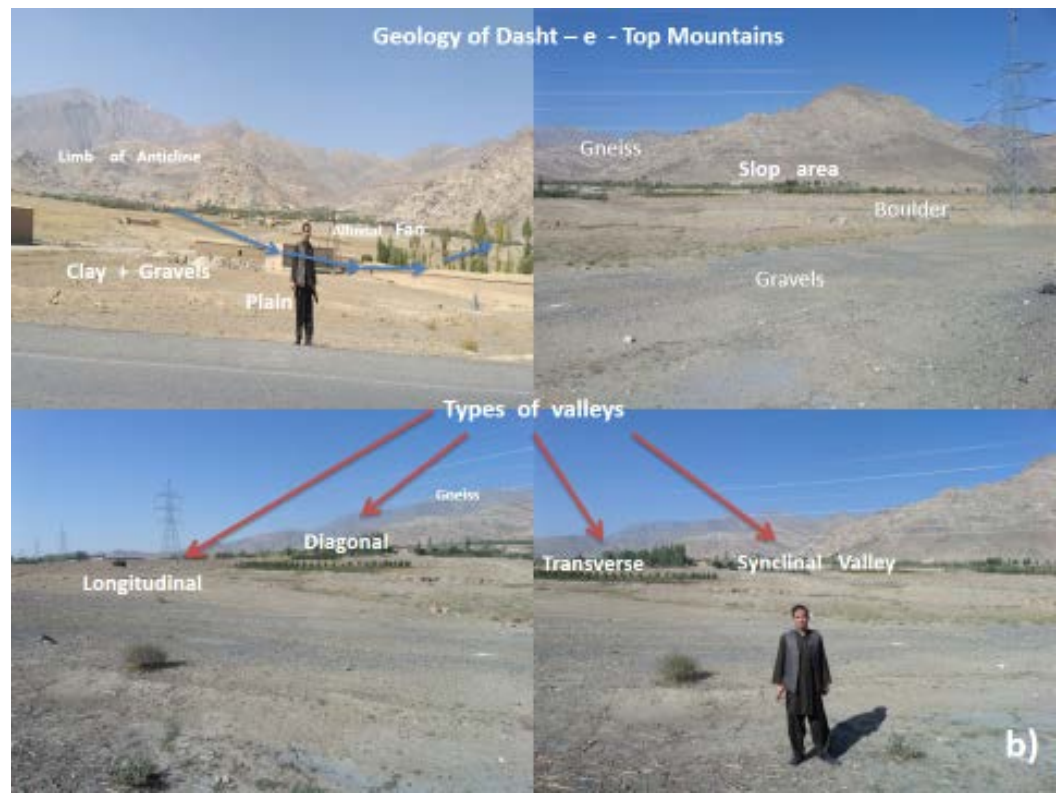

Figure 3. Different geological structures in Dasht-e-top basin.

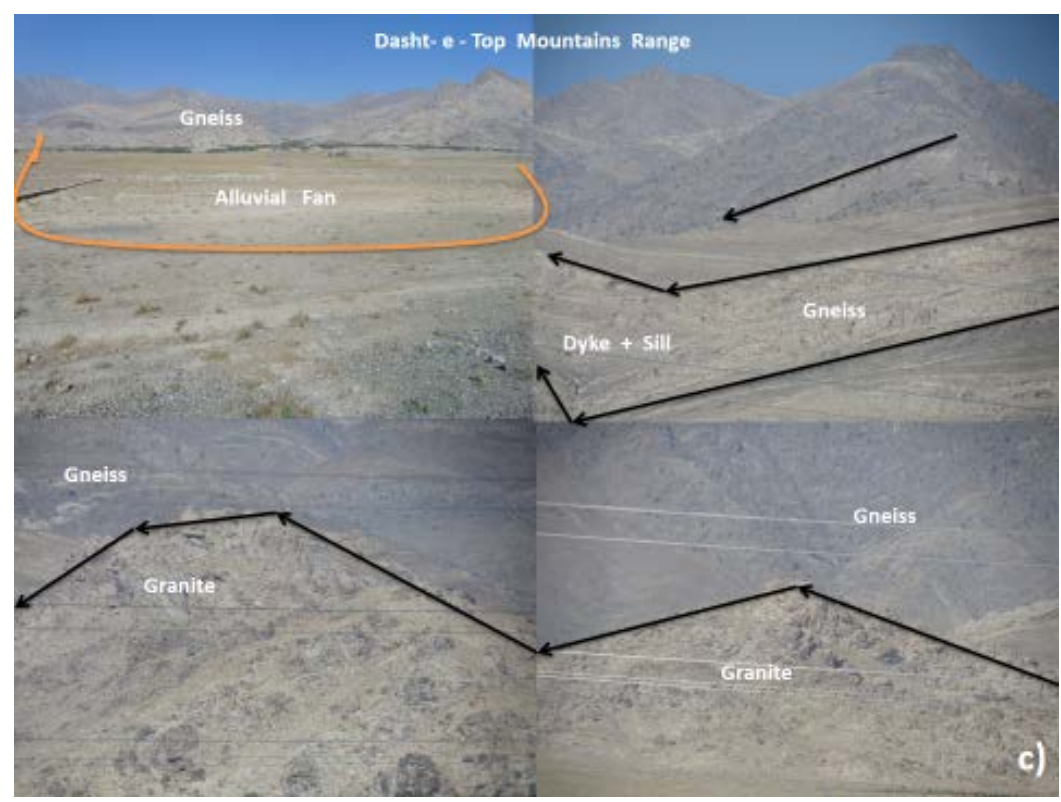

Figure 4. Different contact zones in gneiss and granite.

\section{Alluvial Fans}

Dasht-e-Top sedimentary basin is relatively plane with many and different types of alluvial fans, these sedimentary features contains different types and sizes of sediments such as gravels, sands, silts and clay, whereas the grain size of sediments are related to the their transportation distance from mountains range, generally as we get close to the mountains range the grain size changes from Course to very Course (boulder, cobble, pebble and granule) and as we get away from mountains the grain sizes change from fine to very fine sediments (sands, silt and clay) (Figure 5). 


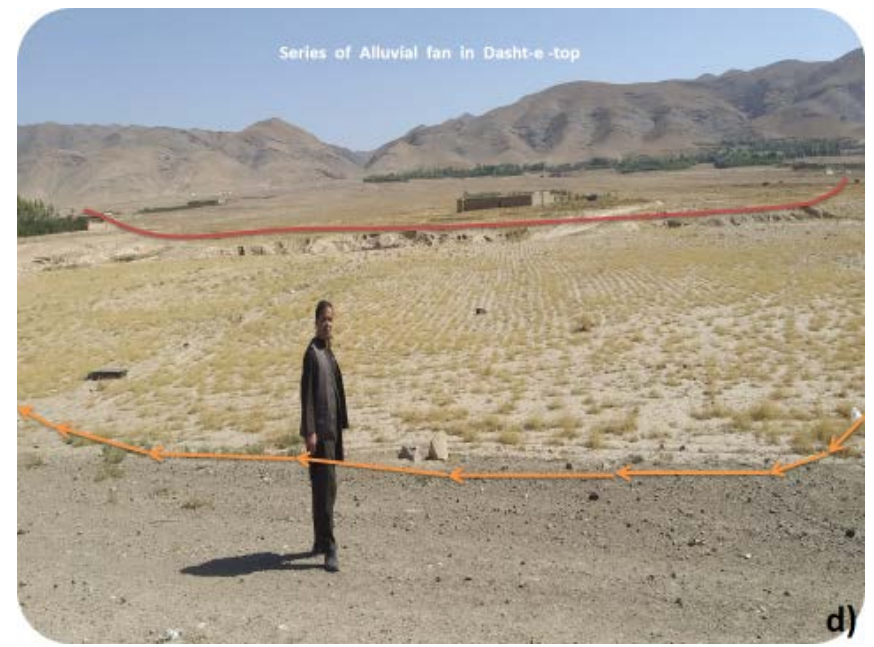

Figure 5. Alluvial fans and different sizes of materials.

\section{Imbrication Bedding}

Imbrication beddings has been clearly observed in this sedimentary basin, where their presence indicates the occurrence of several flooding's at different time periods. From analysis of the observed imbrication beddings, it is found that it contains different types of sedimentary materials which are eroded from different parent rocks, mainly Quartzite, Gneiss, and Granite. Where the main mineral composition of the main rocks available was Quartz, Feldspars, Garnets, and mica minerals. The mentioned bedding type observed, has alternate layers of different sizes of sediments, where it also can be due to periodic occurrence of flooding in the area (Figure 6).

\section{River Terraces and Soil Profiles}

The soil profile studied in the study area include different layers of soil which contains cracks and joints, also the roots of plants are visible up to about $1.15 \mathrm{~m}$ depth. Several small caves which are made by insects and worms can be seen as well. The river terraces present in the area has mainly contains fine sedimentary material such as sand, silt and clay, where from that, it can be judged that there were laminar flows at the area in the past (Figure 7).

The river terraces studied contains different sedimentary structure such as potholes, angular and erosional unconformities, and layer thinning outs. Furtherer more, as there is no specific arrangement in the present sedimentary material in the area, it can be judged as due to the different flow directions (Figure 7 \& Figure 8).

The specific soil profile studied in the area contains different soil structures such as crumbling, platy, single grain, granular and prismatic. Furthermore, the profile were consisting from sands, silts, and clay, with thin layers of course material (gravel), and in general the soil type can be judged as clayey Loam, where organic material and $\mathrm{CaCO}_{3}$ depositions were also available in the seen profile (Figure 9 \& Figure 10). 


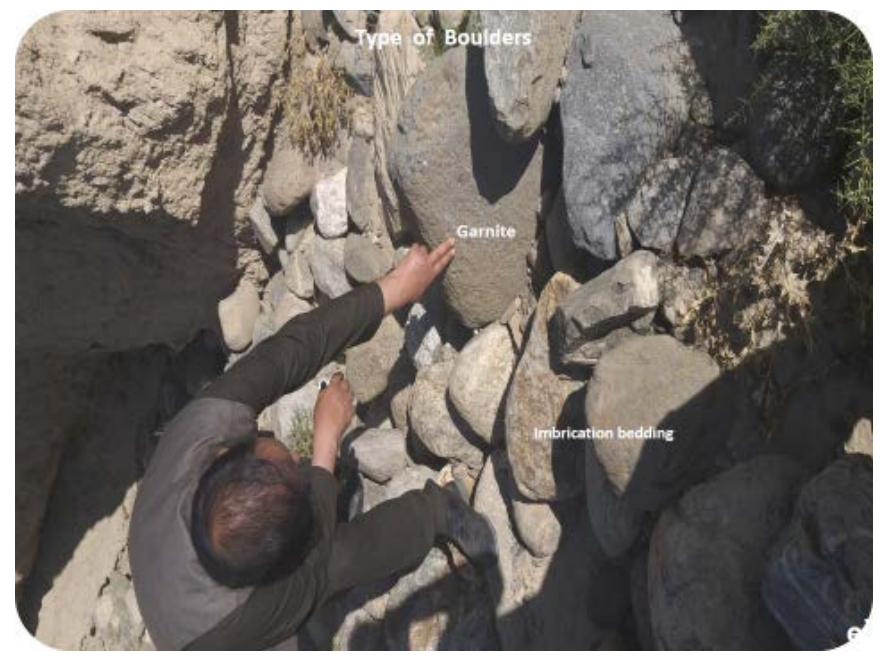

Figure 6. Imbrication bedding with different types and sizes of sediments at Dasht-e-top sedimentary basin.

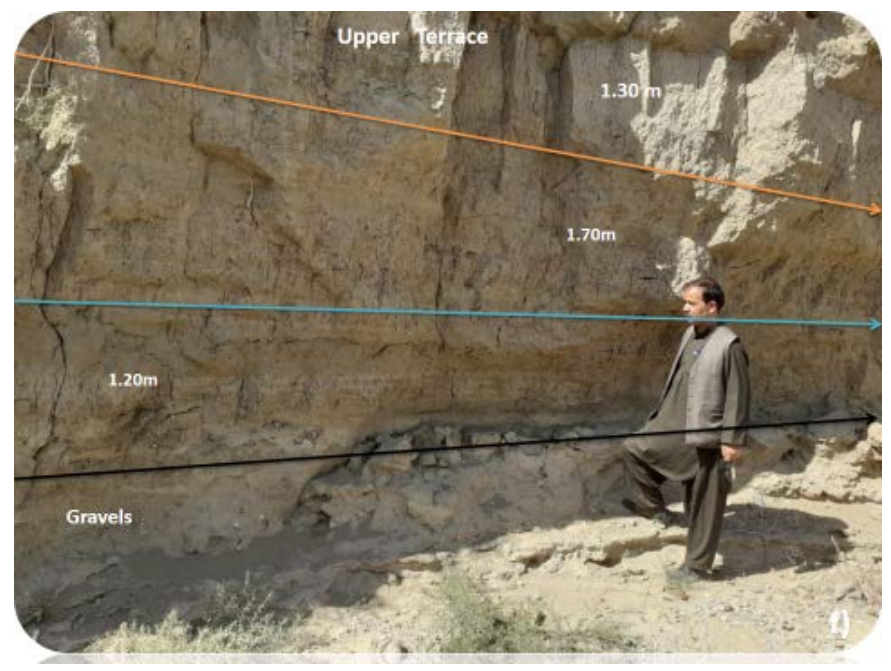

Figure 7. Upper part of River terrace at the Dasht-e-top basin.

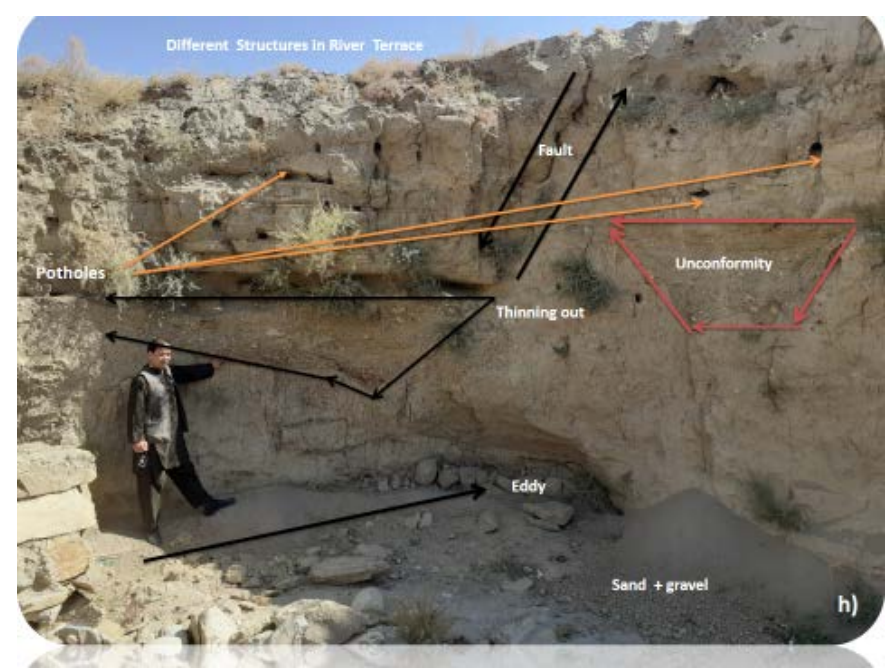

Figure 8. Different structures in river terrace at the Dasht-e-top sedimentary basin. 


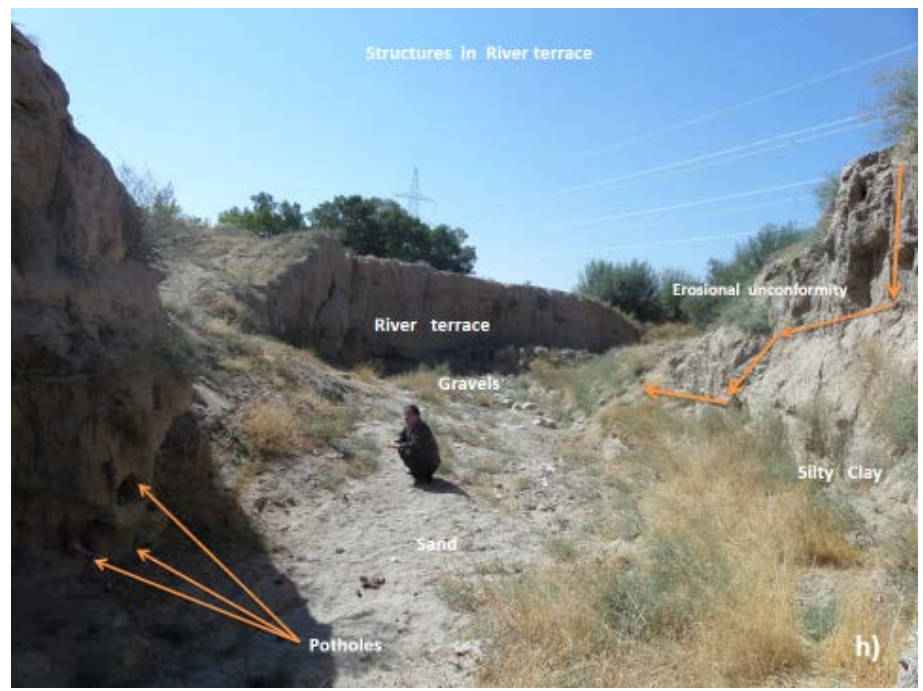

Figure 9. Dry river profile and river terraces in Dasht-e-top basin.

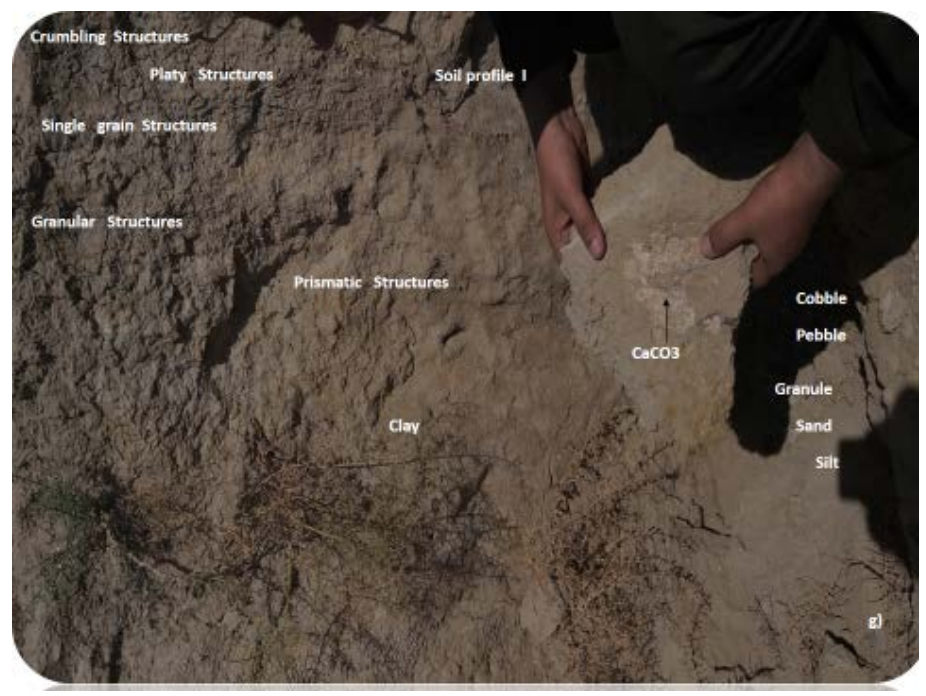

Figure 10. Soil profile in Dasht-e-top basin.

\section{Conclusions}

All sedimentary basins in Afghanistan are belonging to the Paleogene (Eocene ad Oligocene) with the age of about $47-23$ million years and are located in intermountain valleys, where, the different types of sediments deposited between these basins are called Paleogene formations. The sedimentary materials present in these basins related to the surrounded mountain ranges which are eroded and transported by different agents, and the above general characteristics are also specifically applicable in Dasht-e-top sedimentary basin.

Furthermore, Dasht-e-top sedimentary basin is specifically an intermountain backing basin where its surrounding mountains which it look like a bowel. The river terraces present in this basin are formed at different geological time periods and one after another.

Summarily, this study expressed the geology, river terraces and soil profiles in 
the Dasht-e-top sedimentary basin of Wardak province, Afghanistan. Where, the obtained results suggest that further in-depth studies and researches on its soil physical and chemical properties, it's all other geological and sedimentological characteristics with special care and accuracy should be performed.

\section{Acknowledgements}

We would like to express our warm gratitude to anonymous referees for their valuable comments. I extend our thanks to our faculty members who helped us put this paper together.

\section{Conflicts of Interest}

The authors declare no conflicts of interest regarding the publication of this paper.

\section{References}

[1] Anthony, E.J. and Héquette, A. (2007) The Grain-Size Characterization of Coastal Sand from the Somme Estuary to Belgium: Sediment Sorting Processes and Mixing in a Tide- and Storm-Dominated Setting. Sedimentary Geology, 202, 369-382. https://doi.org/10.1016/j.sedgeo.2007.03.022

[2] Coe, A.L. (2003) The Sedimentary Records of Sea Level Change. British Library, 46.

[3] Ball, M.M. (2003) Carbonate Sand Bodies of Florida and Bahamas. Journal of Sedimentary Petrology, 37, 556-591.

[4] Belhassan, K. (2020) Hydrogeology of the Ribaa-Bittit Springs in the Mikkes Basin (Morocco). International Journal of Water Resources and Environmental Science, 9, 7-15.

[5] Belhassan, K. (2020) Relationship between River and Groundwater: Water Table Piezometry of the Mikkes Basin (Morocco). International Journal of Water Resources and Environmental Science, 9, 1-6.

[6] Broshears, R.E., Akbari, M.A., Chornack, M.P., Mueller, D.K. and Ruddy, B.C. (2005) Inventory of Ground-Water Resources in the Kabul Basin, Afghanistan: U.S. Geological Survey. Scientific Investigations Report 2005-5090, 34 p. https://doi.org/10.3133/sir20055090

[7] Bohannon, R.G. and Turner, K.J. (2007) Geologic Map of Quadrangle 3468, Chak Wardak-Syahgerd (509) and Kabul (510) Quadrangles, Afghanistan: U.S. Geological Survey. Open-File Report 2005-1107-A. 1 Sheet.

[8] Bohannon, R.G. (2005) Geologic Map of Quadrangle 3468, Chak-e-Wardak (509) and Kabul (510) Quadrangles: Afghan Open-File Report (509/510) 2005-1001.

[9] Colella, A. and di Geronimo, I. (1998) Surface Sediments and Macro Fanas of the Grati Submarine Fan (Ionian Sea, Italy) Sedimentary Geology. 77.

[10] Elliott, T. (1999) Deltas. In: Reading, H.G., Ed., Sedimentary Environments and Facies, 2nd Edition, Blackwell Scientific Pub., Oxford, 154.

[11] Arian, H., Kayastha, R.B., Bhattarai, B.C., Shrestha, A., Rasouli, H. and Armstrong, R. (2015) Application of the Snowmelt Runoff Model in the Salang River Basin, Afghanistan Using MODIS Satellite. Journal of Hydrology and Meteorology, 9, 109-118. https://doi.org/10.3126/jhm.v9i1.15586

[12] Elliontt, T. (2001) Siliciclastic Shorelines Sedimentary Environments and Facies. 
2nd Edition, Blackwell Scientific Pub., Oxford, 85.

[13] Folk, R.L. (2004) Spectral Division of Limestone Types. In: Hamm, W.E., Ed., Classification of Carbonate Rocks, Memoirs of the American Association of Petroleum Geology, Tulsa, 62-84, 97.

[14] Goff, J., McFadgen, B. and Chagué-Goff, C. (2004) Sedimentary Differences between the 2002 Easter Storm and the 15th-Century Okoropunga Tsunami, Southeastern North Island, New Zealand. Marine Geology, 204, 235-236. https://doi.org/10.1016/S0025-3227(03)00352-9

[15] Horikawa, K. and Ito, M. (2009) Non-Uniform Across-Shelf Variations in Thickness, Grain Size, and Frequency of Turbidities in a Transgressive Outer-Shelf, the Middle Pleistocene Kakinokidai Formation, Boso Peninsula, Japan. Sedimentary Geology, 220, 105-110. https://doi.org/10.1016/j.sedgeo.2009.07.002

[16] Kortekaas, S. and Dawson, A. (2007) Distinguishing Tsunami and Storm Deposits: An Example from Martinhal, SW Portugal. Sedimentary Geology, 200, 208-210. https://doi.org/10.1016/j.sedgeo.2007.01.004

[17] Morton, R.A., Gelfenbaum, G. and Jaffe, B.E. (2007) Physical Criteria for Distinguishing Sandy Tsunami and Storm Deposits Using Modern Examples. Sedimentary Geology, 200, 184-189. https://doi.org/10.1016/j.sedgeo.2007.01.003

[18] Leeder, M. (2006) Sedimentology and Sedimentary Basins. Grphicraft, Ltd., Hong Kong, Raplika Press Pvt. Ltd., Kundli, 193.

[19] Rasouli, H., Kayastha, R.B., Bikas, C.B., Ahuti, S., Arian, H. and Armstrong, R. (2015) Estimation of Discharge from Upper Kabul River Basin, Afghanistan Using the Snowmelt Runoff Model. Journal of Hydrology and Meteorology, 9, 85-94. https://doi.org/10.3126/jhm.v9i1.15584

[20] Rasouli, H. (2017) Study on River Terraces in Upper and Middle Parts of Kabul Sedimentary Basin, Afghanistan. International Journal of Science and Research (IJSR), 6, 1696-1704.

[21] Rasouli, H. (2019) A Study on Some River Sediments, Hydrology and Geological Characteristics in Chak Sedimentary Basin, Wardak, Afghanistan. International Journal of Geology, Earth and Environmental Sciences, 9, 49-61.

[22] Ruleman, C.A., Crone, A.J., Machette, M.N., Haller, K.M. and Rukstales, K.S. (2007) Map and Database of Probable and Possible Quaternary Faults in Afghanistan: U.S. Geological Survey. Open File Report 2007-1103, 39 p.

[23] Rubin, D.M.A. (2004) Simple Autocorrelation Algorithm for Determining Grain Size from Digital Images of Sediment. Journal of Sedimentary Research, 74, 160-165. https://doi.org/10.1306/052203740160

[24] Sedgwick, P.E. and Davis, R.A. (2003) Stratigraphy of Washover Deposits in Florida: Implications for Recognition in the Stratigraphic Record. Marine Geology, 200, 31-32. https://doi.org/10.1016/S0025-3227(03)00163-4

[25] Sun, Y., Gao, S. and Li, J. (2003) Preliminary Analysis of Grain-Size Populations with Environmentally Sensitive Terrigenous Components in Marginal Sea Setting. Chinese Science Bulletin, 48, 184-186. https://doi.org/10.1360/03tb9038 